\title{
PENGARUH ORIENTASI KEWIRAUSAHAAN DAN MANAJEMEN KUALITAS \\ TERHADAP KEUNGGULAN BERSAING USAHA MIKRO, KECIL, DAN \\ MENENGAH (UMKM) INDUSTRI PANGAN \\ DI KOTA BENGKULU
}

\author{
EFFECT OF ORIENTATION ENTREPRENEURSHIP AND QUALITY \\ MANAGEMENT OF COMPETITIVE ADVANTAGES OF MICRO, SMALL AND \\ MEDIUM ENTERPRISES (SMES) FOOD INDUSTRY \\ AT BENGKULU CITY
}

Darius

Program Studi Teknologi Pertanian Fakultas Pertanian Universitas Dehasen Bengkulu

\begin{abstract}
ABSTRAK
UMKM sebagai pengerak pengembangan potensi wilayah yang berbasis ekonomi kerakyatan. Pelaku UMKM industi pangan di Kota Bengkulu yang memiliki orientasi kewirausahaan dapat mengembangkan kegiatan usahanya dan memperluas pangsa pasar dengan menghasilkan produk yang berkualitas sehingga mampu bertahan dalam persaingan dunia usaha yang semakin dinamis. Penelitian ini bertujuan menganalisis dan mengetahui pengaruh orientasi kewirausahaan atau manajemen kualitas terhadap keunggulan bersaing UMKM industri pangan di Kota Bengkulu.. Penelitian ini menggunakan pendekatan survei dengan metode pengambilan sampel menggunakan metode purposive sampling dengan jumlah sampel sebanyak 118 responden dan dianalisis dengan regresi linier sederhana. Hasil dari penelitian ini adalah: orientasi kewirausahaan berpengaruh terhadap keunggulan bersaing UMKM industri pangan di Kota Bengkulu dan manajemen kualitas berpengaruh terhadap keunggulan bersaing UMKM industri pangan di Kota Bengkulu.
\end{abstract}

Kata kunci: orientasi kewirausahaan, manajemen kualitas, keunggulan bersaing, UMKM industri pangan

\section{ABSTRACT}

SMEs as a driver of development potential of the area-based social economy. SMEs in the food industry, the city of Bengkulu who have an entrepreneurial orientation can develop their business activities and expand market share by producing a quality product that is able to survive in the competitive business world that is increasingly dynamic. This study aims to analyze and determine the effect of orientation entrepreneurship or quality management to competitive advantage SME food industry in the city of Bengkulu. This study used a survey approach to sampling methods using purposive sampling method with a total sample of 118 respondents and analyzed by simple linear regression. The results of this study are: orientation entrepreneurship influence the food industry the competitive advantage of SMEs in the city of Bengkulu and quality management influence the competitive advantage of SMEs in the food industry city of Bengkulu.

Keywords: orientation entrepreneurship, quality management, competitive advantage, SMEs food industry 


\section{PENDAHULUAN}

Usaha Mikro Kecil dan Menengah (UMKM) sebagai pengerak pengembangan potensi wilayah yang berbasis ekonomi kerakyatan. Adapun karakteristik dari UMKM adalah: proses produksi bersifat padat karya, skala usaha kecil, dimiliki oleh perorangan, tidak ada pemisahan antara pemilik dengan manajerial. berusaha pada sektor informal, responsif dalam memenuhi kebutuhan konsumen, penerapan teknologi masih rendah, lebih cepat dalam penyediaan lapangan kerja, dan memberdayakan tenaga kerja lokal.

Pemerintah Bengkulu telah meluncurkan program Samisake (Satu Milyar Satu Kelurahan) sejak tahun 2012 dalam mendukung dan mengakomodasi kebutuhan modal dari para pelaku UMKM dalam mengembangkan usahanya dengan disertai melakukan sosialisasi serta pelatihan mengenai kewirausahaan. Pelaksanaan program Samisake telah memberikan pengaruh yang baik dan signifikan dalam perkembangan UMKM dan pertumbuhan perekonomian di daerah Kota Bengkulu.

Beberapa masalah yang ada dari pelaku UMKM industri pangan di Kota Bengkulu dalam menjalankan kegiatan usahanya diantaranya: jumlah modal usaha kecil sehingga sulit melakukan pengembangan produk yang kompetitif, kegiatan usahanya dilakukan secara turun temurun, sering berganti-ganti kegiatan usaha, aspek kualitas pada proses pengolahan, produk, dan lingkungan usaha belum menjadi yang diutamakan, keterbatasan dalam penggunaan teknologi pengembangan pangsa pasar yang masih lemah, dan informasi pasar mengenai apa yang menjadi keinginan dan kebutuhan dari konsumen masih terbatas.

Orientasi kewirausahaan menjadi sesuatu yang kritis bagi perusahaan yang menghadapi persaingan dan tekanan dalam pasar yang terus meningkat (Slater and Narver, 1995). Pelaku UMKM industri pangan yang memiliki orientasi kewirausahaan yang baik dapat mengembangkan kegiatan usahanya dengan berorientasi pada kebutuhan pasar. Keberhasilan UMKM industri pangan di Kota Bengkulu dalam memperluas pangsa pasar dan mampu bertahan dalam persaingan dunia usaha yang semakin dinamis adalah dengan menghasilkan produk yang berkualitas sesuai.standar mutu yang telah ditetapkan agar mampu memenuhi harapan dan keinginan konsemen dalam memenuhi kebutuhannya.

Berdasarkan uraian, maka perumusan permasalahan pada penelitian ini adalah: 1) apakah orientasi kewirausahaan berpengaruh terhadap keunggulan bersaing UMKM industri pangan di Kota 
Bengkulu dan 2) apakah manajemen kualitas berpengaruh terhadap keunggulan bersaing UMKM industri pangan di Kota Bengkulu.

Lingkungan usaha yang dinamis mengharuskan perusahaan memiliki orientasi kewirausahaan agar mampu berhasil bersaing dengan perusahaan lainnya. Keunggulan bersaing hanya dapat dicapai dengan melakukan strategi pemasaran yang responsif dan agresif ketika berhadapan dengan pesaing sehingga dapat bersaing lebih efektif dalam mendominasi pangsa pasar (Porter, 1990). Orientasi kewirausahaan berpengaruh terhadap keunggulan bersaing dalam kualitas maupun bagi perusahaan (Anriyani (2005).

$\begin{array}{lllll}\text { Hipotesis } & 1 & \left(\mathrm{H}_{1}\right) & \text { : } & \text { Orientasi }\end{array}$ kewirausahaan mempunyai pengaruh yang signifikan terhadap keunggulan bersaing
UMKM industri pangan di Kota Bengkulu.

Implementasi manajemen kualitas dalam suatu organisasi sangat penting dalam mencapai keunggulan bersaing dengan memberikan penekanan pada kualitas produk dan pelayanan (Sila et al, 2007). Penerapan manajemen kualitas memberikan pengaruh yang positif dan signifikan terhadap keunggulan bersaing perusahaan. Penerapan manajemen kualitas yang semakin baik maka keunggulan bersaing perusahaan akan semakin baik (Ramlawati, dkk, 2011).

Hipotesis $2\left(\mathrm{H}_{2}\right) \quad$ : $\quad$ Manajemen

kualitas mempunyai pengaruh yang signifikan terhadap keunggulan bersaing UMKM industri pangan di Kota Bengkulu. Kerangka berpikir dalam penelitian ini seperti pada gambar 1 .

\section{Orientasi Kewirausahaan (X1): \\ 1. Berani mengambil risiko \\ 2.Proaktif \\ 3. Inovatif \\ (Lumpkin and Dess, 1996)}

Manajemen Kualitas (X2):

1. Kemampuan proses

2. Spesifikasi yang berlaku

3. Tingkat ketidaksesuaian yang dapat diterima

4. Biaya kualitas

(Douglas C. Montgomery dalam

Fakhri, 2010)
Keunggulan Bersaing (Y):

1. keunikan produk

2. harga bersaing

3. jarang dijumpai

4. tidak mudah ditiru

5. tidak mudah digantikan

(Porter, 1990)

\section{Gambar 1. Kerangka Pikir Penelitian}




\section{METODE PENELITIAN}

Pendekatan penelitian menggunakan pendekatan survey, populasi penelitian adalah semua UMKM yang ada di Kota Bengkulu tahun 2015 sebanyak 1.133 UMKM (Dinas Koperasi dan PPKM Kota Bengkulu, 2015), sampel penelitian adalah UMKM dengan bidang usaha industri sebanyak 118 responden dengan metode pengambilan sampel menggunakan metode purposive sampling. Data penelitian dianalisis dengan regresi linier sederhana, yang terlebih dahulu dilakukan pengujian atas kualitas dan asumsi klasik pada data penelitian.

\section{HASIL DAN PEMBAHASAN}

Kualitas data penelitian diuji menggunakan uji validitas Pearson correlation dan uji reliabilitas dengan teknik Cronbach alpha. Hasil pengujian kualitas data penelitian pada tabel 1 .

Berdasarkan tabel 1 menunjukkan nilai korelasi Pearson dari uji validitas untuk setiap data pada variabel penelitian adalah signifikan pada $\alpha=0,01$, yang berarti bahwa data penelitian yang digunakan adalah valid. Setiap data pada variabel penelitian dari uji reliabilitas memiliki nilai Cronbach alpha $>0,6$ sehingga data penelitian yang digunakan adalah reliable. Data penelitian yang bernilai valid dan reliable tersebut dapat dipergunakan dalam pengujian hipotesis penelitian.

Hasil pengujian normalitas data dengan menggunakan uji Kolmogorof-Smirnof dengan $\alpha=5 \%$ pada tabel 2 .

Tabel 1. Uji Validitas dan Reliabilitas Data Penelitian

\begin{tabular}{lcc}
\hline \multicolumn{1}{c}{ Variabel } & Cronbach alpha & Pearson Correlation \\
\hline Orientasi Kewirausahaan & 0,689 & $0,766^{* *}-0,798^{* *}$ \\
Manajemen Kualitas & 0,635 & $0,602 * *-0,758^{* *}$ \\
Keunggulan Bersaing & 0,812 & $0,701 * *-0,832 * *$ \\
\hline
\end{tabular}

** Signifikan pada level 0,01

Tabel 2. Uji Normalitas Data Penelitian

\begin{tabular}{lccc}
\hline \multicolumn{1}{c}{ Variabel } & $\mathrm{N}$ & p-value & Keterangan \\
\hline Orientasi Kewirausahaan & 118 & 0,096 & Normal \\
Manajemen Kualitas & 118 & 0,067 & Normal \\
Keunggulan Bersaing & 118 & 0,071 & Normal \\
\hline
\end{tabular}


Berdasarkan tabel 2 menunjukkan data dari setiap variabel penelitian memiliki nilai $p$-valuenya lebih besar dari $\alpha=0,05$. Hal ini berarti data penelitian dari semua variabel penelitian yang digunakan berdistribusi normal dan dapat dipergunakan dalam pengujian hipotesis penelitian.

Cara untuk mengetahui ada tidaknya multikolinearitas data suatu data yaitu dengan melihat besarnya nilai tolerance value atau Variance Inflation Factor (VIF) (Hair, dkk, 1998). Hasil pengujian multikolinearitas pada data penelitian pada tabel 3 .

Tabel 3 menunjukkan data dari semua variabel penelitian memiliki nilai Variance Inflation Factor (VIF) $\leq 10$ dan nilai tolerance $\geq 0,10$. Hal ini berarti tidak ada dan terjadi multikolinearitas pada data dari semua variabel penelitian. Modelmodel regresi linier sederhana pada penelitian ini telah memenuhi asumsi yang diminta dan terbebas dari adanya multikolinearitas, sedangkan hasil pengujian hipotesis 1 pada tabel 4 .

Tabel 3. Hasil Pengujian Multikolinearitas Data Penelitian

\begin{tabular}{lcrl}
\hline \multirow{1}{*}{\multicolumn{1}{c}{ Variabel }} & \multicolumn{2}{c}{$\begin{array}{c}\text { Collinearity } \\
\text { Statistic }\end{array}$} & Keterangan \\
\cline { 2 - 3 } & Tolerance & VIF & \\
\hline Orientasi Kewirausahaan & 1,000 & 1,000 & Tidak ada multikolinearitas \\
Manajemen Kualitas & 1,000 & 1,000 & Tidak ada multikolinearitas \\
Keunggulan Bersaing & 1,000 & 1,000 & Tidak ada multikolinearitas \\
\hline
\end{tabular}

Tabel 4. Regresi Linier Sederhana pada Uji Hipotesis 1

\begin{tabular}{lcccc}
\hline \multicolumn{1}{c}{ Variabel } & Koefisien & Nilai Koefisien & t-hitung & Sig. \\
\hline Konstanta & $\alpha_{1}$ & 7,273 & 4,828 & 0,000 \\
Orientasi Kewirausahaan & $\beta_{1}$ & 1,040 & 8,368 & 0,000 \\
$(\mathrm{X} 1)$ & $\mathrm{F}=70,017$ & $\mathrm{p}=0,000$ & $\mathrm{n}=118$ & \\
$\mathrm{R}^{2}=0,227$ & & & & \\
\hline
\end{tabular}


Variabel orientasi kewirausahaan memiliki nilai signifikan ( $\mathrm{sig}$ ) untuk t-hitung $=4,828$ lebih besar dari nilai $\mathrm{t}$-tabel $=\mathrm{t}_{(2,116)}=$ 1,9813 pada tingkat signifikansi $(\alpha)=5 \%$. Nilai signifikan (sig) dari orientasi kewirausahaan $=0,000$ lebih kecil dari nilai $\alpha=5 \%$. Berdasarkan nilai t-hitung dan nilai signifikan (sig) tersebut dapat disimpulkan bahwa orientasi kewirausahaan mempunyai pengaruh yang signifikan terhadap keunggulan bersaing UMKM industri pangan di Kota Bengkulu.

Nilai koefisien determinasi $\mathrm{R}^{2}=0,376$ berarti bahwa orientasi kewirausahaan mempunyai pengaruh yang signifikan sebesar $37,6 \%$ terhadap keunggulan bersaing UMKM industri pangan di Kota Bengkulu. Keunggulan bersaing UMKM industri pangan di Kota Bengkulu sebesar $62,4 \%$ dipengaruhi oleh variabel-variabel lainnya yang tidak diteliti atau di luar dari penelitian ini.

Hasil pengujian hipotesis 2 pada tabel 5 . Variabel manajemen kualitas memiliki nilai signifikan (sig) untuk t-hitung $=$ 10,576 lebih besar dari nilai $\mathrm{t}$-tabel $=\mathrm{t}$ $(2,116)=1,9813$ pada tingkat signifikansi $(\alpha)=5 \%$. Nilai signifikan (sig) dari manajemen kualitas $=0,000$ lebih kecil dari nilai $\alpha=5 \%$. Berdasarkan nilai $\mathrm{t}$ hitung dan nilai signifikan (sig) tersebut dapat disimpulkan bahwa manajemen kualitas mempunyai pengaruh yang signifikan terhadap keunggulan bersaing UMKM industri pangan di Kota Bengkulu.

Nilai koefisien determinasi $R^{2}=0,491$ berarti bahwa manajemen kualitas mempunyai pengaruh yang signifikan sebesar 49,1\% terhadap keunggulan bersaing UMKM industri pangan di Kota Bengkulu. Keunggulan bersaing UMKM industri pangan di Kota Bengkulu sebesar $50,9 \%$ dipengaruhi oleh variabel-variabel lainnya yang tidak diteliti atau di luar dari penelitian ini.

Tabel 5. Regresi Linier Sederhana pada Uji Hipotesis 2

\begin{tabular}{lcccc}
\hline \multicolumn{1}{c}{ Variabel } & Koefisien & Nilai Koefisien & t-hitung & Sig. \\
\hline Konstanta & $\alpha_{2}$ & 3,563 & 2,309 & 0,023 \\
Manajemen Kualitas (X2) & $\beta_{2}$ & 1,182 & 10,576 & 0,000 \\
$\mathrm{R}^{2}=0,491$ & $\mathrm{~F}=111,842$ & $\mathrm{p}=0,000$ & $\mathrm{n}=118$ & \\
\hline
\end{tabular}

Aspek orientasi kewirausahaan yang dimiliki oleh UMKM industri pangan di
Kota Bengkulu mempunyai pengaruh yang signifikan terhadap keunggulan 
bersaing UMKM industri pangan di Kota Bengkulu. Hasil penelitian ini menunjukkan bahwa ada pengaruh yang positif antara orientasi kewirausahaan terhadap keunggulan bersaing UMKM industri pangan di Kota Bengkulu, berupa: dimilikinya sikap inovatif, proaktif, dan berani mengambil risiko. Orientasi kewirausahaan berpengaruh terhadap keunggulan bersaing UMKM industri pangan di Kota Bengkulu sebesar 37,6\% dan selebihnya $62,4 \%$ dipengaruhi faktorfaktor lainnya yang tidak diteliti dan berada di luar penelitian ini.

Aspek manajemen kualitas yang diterapkan oleh UMKM industri pangan di Kota Bengkulu mempunyai pengaruh yang signifikan terhadap keunggulan bersaing UMKM industri pangan di Kota Bengkulu. Hasil penelitian ini menunjukkan bahwa ada pengaruh yang positif antara manajemen kualitas terhadap keunggulan bersaing UMKM industri pangan di Kota Bengkulu, berupa: kemampuan dalam proses pengolahan bahan pangan, adanya alokasi biaya kualitas, ada penetapan standar dalam menghasilkan produk yang berkualitas, dan adanya pemberlakuan tingkat ketidaksesuaian yang dapat diterima atas pemilihan bahan baku, proses proses pengolahan, dan produk yang dihasilkan. Manajemen kualitas berpengaruh terhadap keunggulan bersaing UMKM industri pangan di Kota Bengkulu sebesar 49,1\% dan selebihnya $50,9 \%$ dipengaruhi faktorfaktor lainnya yang tidak diteliti dan berada di luar penelitian ini.

Aspek keunggulan bersaing yang dimiliki UMKM industri pangan di Kota Bengkulu adalah: produk yang dihasilkan tidak mudah ditiru oleh produk UMKM lainnya, penentuan dan penetapan harga produk yang dihasilkan untuk dijual disesuaikan dengan tingkat harga produk yang sejenis dari UMKM lainnya, produk yang dihasilkan berbeda dan memiliki kekhasan dengan produk UMKM lainnya, produk yang dihasilkan belum memiliiki produk substitusinya, dan produk yang dihasilkan masih jarang ditemukan di pasaran. Keunggulan bersaing dari UMKM industri pangan di Kota Bengkulu harus dipertahankan dan terus ditingkatkan secara berkesinambungan agar UMKM industri pangan dapat bertahan dan mampu bersaing dalam lingkungan persaingan pasar yang semakin dinamis dan ketat, serta harapan dan keinginan konsumen akan produk yang berkualitas semakin meningkat.

\section{SIMPULAN}

Simpulan dari penelitian ini adalah: 1) orientasi kewirausahaan berpengaruh terhadap keunggulan bersaing UMKM industri pangan di Kota Bengkulu dan 2) manajemen kualitas berpengaruh terhadap 
keunggulan bersaing UMKM industri pangan di Kota Bengkulu.

\section{DAFTAR PUSTAKA}

Anriyani. 2005. Analisis Pengaruh Orientasi Kewirausahaan terhadap Strategi Pemasaran Guna Meningkatkan Kinerja Perusahaan (Studi Kasus pada UKM Mebel di Jawa Tengah). Tesis. Semarang: Universitas Diponegoro.

Dinas Koperasi dan PPKM Kota Bengkulu. 2015. Laporan Hasil Pendataan Usaha Mikro Kecil dan Menengah Tahun Anggaran 2015 di Kota Bengkulu. Bengkulu: Dinas Koperasi dan PPKM Kota Bengkulu.

Fakhri, Faiz Al. 2010. Analisis Pengendalian Kualitas Produksi di PT. Masscom Grahpy dalam Upaya Mengendalikan Tingkat Kerusakan Produk Menggunakan Alat Bantu Statistik. Skripsi Dipublikasikan. Diakses tanggal 20 Februari 2016, dari http://www.google.com.

Hair, J.F., Anderson, R.E., Black, W.C. 1995. Multivariate Data Analysis
With Reading. Fourth Edition. U.S: Prentice Hall International.

Lumpkin G.T. and Dess G.G. 1996. Clarifying the Entreprenuerial Orientation Construct and Linking it to Performance. Academy of Management Review, Vol 21 No.1.

Porter, Michael, E. 1990. Competitive Strategy. The Free Press. New York.

Ramlawati, Surachman, Djumilah Zain, dan Djumahir. 2011. Implikasi Praktek Total Quality Management (TQM) terhadap Daya Saing, Kepuasan Konsumen, dan Kinerja Bisnis pada Perusahaan Manufaktur di Kota Makassar. Jurnal Aplikasi Manajemen, Volume 9 Nomor 3, Mei 2011. Fakultas Ekonomi dan Bisnis Universitas Brawijaya.

Sila, I. 2007. Examining The Effects of Contextual Factors on TQM and Performance Through The Lens of Organizational Theories: An Empirical Study. Journal of Operations Management, 25, 83109.

Slater, S.F, and Narver, J.C. 1995. Market Orientation and Learning Organization. Journal of Marketing, 59 (July), 63-74. 